\title{
International business responses to institutional voids
}

\author{
Jonathan Doh ${ }^{1}$, \\ Suzana Rodrigues ${ }^{2}$, \\ Ayse Saka-Helmhout ${ }^{3}$ and \\ Mona Makhija ${ }^{4}$ \\ ${ }^{1}$ Villanova School of Business, Villanova, \\ PA 19085, USA; ${ }^{2}$ FUMEC University, Brazil \& \\ Rotterdam Business School, Erasmus University, \\ Rotterdam, The Netherlands; ${ }^{3}$ Nijmegen School of \\ Management, Radboud University, Nijmegen, The \\ Netherlands; ${ }^{4}$ The Ohio State University, 724 \\ Fisher Hall, Columbus, OH 43210, USA
}

\section{Correspondence:}

M Makhija, The Ohio State University, 724

Fisher Hall, Columbus, OH 43210, USA

e-mail: makhija.2@osu.edu

\begin{abstract}
For nearly two decades, scholars in international business and management have explored the implications of institutional voids for firm strategy and structure. Although institutional voids offer both opportunities and challenges, they have largely been associated with firms' efforts to avoid or mitigate institutional deficiencies and reduce the transaction costs associated with operating in settings subject to those institutional shortcomings. The goal of this special issue is to advance scholarship on this topic by (a) exploring institutional voids that are new to the literature, (b) providing a deeper assessment of the different ways in which firms respond to these voids, and (c) utilizing diverse disciplines and theoretical approaches to do so. In this introduction, we first review and synthesize extant research on institutional voids, tracking the evolution of institutional void scholarship since the inception of the concept (Khanna \& Palepu, Journal of Economic Literature, 45(2):331-372, 1997) and providing our perspective on its contributions and limitations. We then summarize the contributions of the articles included in this special issue. In addition to identifying an array of institutional voids - economic and social - the articles highlight four different strategies for responding to them: internalization, substitution, borrowing and signaling. Drawing on these, we develop new insights on the implications of institutional voids for firm behavior. We conclude with suggestions for future research.
\end{abstract}

Journal of International Business Studies (2017) 48, 293-307. doi: 10.1057/s41267-017-0074-z

Keywords: Institutions and International business; institutional voids; Multinational Corporations (MNCs) and Enterprises (MNEs); market and nonmarket strategies; transaction costs

\section{INTRODUCTION}

For the past several decades, an important concern for international business scholarship has been to further understanding on how variations in formal and informal institutions influence economic activities. While it has been evident for some time that countries differ significantly in their institutional composition, particularly among developed and emerging economies, how these differences influence the strategic choices of firms was less clear. It is for this reason that the concept of institutional voids - the absence or underdevelopment of institutions that enable and support market activity (Khanna \& Palepu, 1997) - has gained increasing attention in the international business literature. Khanna and Palepu's (1997) article motivated a new way to understand firms' strategies in 
emerging markets, focusing on tensions and paradoxes in firms' interactions with institutions in these countries. Rather than considering institutions as "givens" that constrain interactions (e.g. Meyer \& Rowan, 1977; DiMaggio \& Powell, 1983), an institutional voids lens encourages a more dynamic approach for examining how firms strategize - alone or in conjunction with other actors - to avoid, remedy (Regnér \& Edman, 2014), compensate, substitute (Boddewyn \& Doh, 2011), shape and even take advantage of institutional weaknesses (Khanna $\&$ Palepu, 2010). By relating home and host country institutional voids to firms' strategic responses, this perspective offers the opportunity to advance IB theory in new directions.

Institutional voids reflect institutional conditions that hamper the ease by which buyers and sellers can interact. The result is higher costs for procuring materials, capital, information, skills, and new ideas, which in turn reduce the likelihood of efficient outcomes. While a given country has a myriad of institutions - rules and policies, governmental structure, cultural norms and standards, among others - making up its institutional environment, an institutional voids lens focuses our attention on those institutions that best explain the workings of its markets and influence their ability to function well. Voids reflect prevailing institutional conditions that disturb the functioning of markets, enhancing the likelihood of opportunism (including corruption), excessive rents to a few actors (reducing entrepreneurship) and market power (discouraging competition). In this way, institutional voids have the capacity to shed important light on key issues that concern international business scholars, such as the effects of institutions on innovation (Carney, Dieleman, \& Taussig, 2016), foreign direct investment (Meyer \& Peng, 2016), and risks (Makhija \& Stewart, 2002).

In contrast to other institutional approaches (e.g., institutional logics, institutional distance) that direct attention to exogenous institutional differences, this notion stresses how institutional features enable organizational action. It makes it clear that each potential void is an actionable construct, that can be reacted to or shaped. For example, firms may mitigate institutional absences or substitute formal institutions by collaborating with local actors (Meyer, Estrin, Bhaumik, \& Peng, 2009; Khanna \& Palepu, 2010) or creating new organizational arrangements (Dahan, Doh, Oetzel, \& Yaziji, 2010; Kostova \& Hult, 2016). To address shortcomings in formal institutions, they may rely more heavily on informal institutions (e.g., Mair, Martí, \& Ventresca, 2012) or influence governments to change institutions (Boddewyn \& Doh, 2011). Rather than taking institutional differences as largely given, appearing as objective and taken for granted by firms, we argue that voids become enabling when firms enact them.

An institutional voids perspective also facilitates consideration of a wider range of institutions that incorporate both market and nonmarket effects on firms. Both market and nonmarket exchange involve institutionalization, rationalization and organization (Biggart \& Delbridge, 2004). Accordingly, we suggest that nonmarket exchanges are embedded in logics other than those of rationality and price, such as social (Granovetter, 1985) and political (Fligstein, 1996). Thus social entrepreneurship (e.g., Stephan, Uhlaner, \& Stride, 2015) and lobbying of governments can affect how markets operate (Boddewyn \& Doh, 2011). Like any social structure, markets come into existence and fail, due to the influence of different types of institutional arrangements that consist of either formal (written rules santioned and enforced by the state) or informal (unwritten rules that are not officially sanctioned and enforced) institutions, or both (North, 1991). By drawing attention to how varying organizational arrangements might substitute for missing institutions, this perspective highlights the strong connection between context and firm strategy. The need to respond to specific institutional voids can also help explain why firms across national contexts differ in terms of their strategies and structures. Thus in addition to providing a logic that helps to isolate the institutional features of a country's environment that are particularly important for firms, it offers a basis for comparison of these features and their effects across national contexts. Nonetheless, it is interesting to note that, barring a few exceptions (i.e., Pinkse \& Kolk, 2012; Stephan, Uhlaner, \& Stride, 2015; Santangelo \& Meyer, 2011), scholarship on responses to institutional voids has not been commonly featured in JIBS or other outlets.

In light of the above, the goal of this special issue was to encourage research that furthered our theoretical understanding of institutional voids in relation to international business. More specifically, the motivation for this special issue was threefold. First, we recognized the need to advance insights on the conceptualization of institutional voids. Research that could potentially help in this regard includes exploration of voids that are new to the literature, comparison of the effects of different types of voids, or examination of how different 
actors might play a role in influencing the structure or severity of voids. Second, we believed there would be value in a deeper assessment of the strategies firms utilize to respond to institutional voids. For example, while the literature has stressed firms' response to voids by internalizing functions that are not available via intermediaries, other market and nonmarket strategies may also play a pertinent role. There may also be systematic variations in the strategies among domestic and foreign firms stemming from differences in resources or knowledge. Finally, in line with the quest to broaden our comprehension of institutional voids, we encouraged submissions that drew from differing disciplines and relied upon different theoretical approaches, including those from sociology, law, economics, management and finance.

This special issue reflects the results of these motivations and objectives. We received over sixty original submissions, but ultimately accepted only five for inclusion in the issue. The articles included here focus on a variety of institutional voids, including familiar ones relating to capital markets, contract enforcement and rule of law, but also new ones relating to governmental dissemination of information and bureaucratic red tape. Although we were interested in firms' responses to institutional voids as well as how firms themselves might challenge or change them, the accepted articles focused primarily on the former. One of the most successful elements of the special issue is the identification of a broader range of strategies for addressing institutional voids than had been previously considered in the literature. To do so, the featured studies either focused on foreign firms operating in host environments or compared domestic firms operating in home environments. As expected, diverse theoretical approaches were employed across the studies to generate novel insights.

Below, we briefly review institutional voids research as it relates to international business, and consider how the goals of this research might further this topic. This is followed by a preview of the articles in this special issue, and a discussion of their contributions to the institutional voids literature. Finally, we set the stage for future research on this topic.

\section{INSTITUTIONAL VOIDS AND INTERNATIONAL BUSINESS}

A fundamental concern in international business research is clarifying the role of context for business activity. The national context within which firms operate can be analysed on different dimensions, but a key element in this regard is the set of institutions, both formal and informal, that are in place and which are believed to have systematic effects on the behavior of firms and the individuals within them (North, 1990). Understanding the relationship between a firm's institutional environment and its strategic choices is therefore of paramount importance to the field. The concept of institutional voids has much potential to shed needed light on this relationship, by helping to direct our attention to the characteristics of institutions that matter most to how firms function. Below we elaborate on the connection between institutions and institutional voids, and their influence on firms.

\section{Institutions and Institutional Voids}

Institutions serve as 'rules of the game' (North, 1990) through their influence on the transaction costs of business activities. Countries differ in how institutions affect the economy, society and businesses (Keefer \& Knack, 1997; Stephan, Uhlaner, \& Stride, 2015; Carney et al., 2016), and therefore, on the type of transaction costs firms may incur in their environments. Indeed, much research has examined the effects of institutions such as regulatory rules and legal norms on a variety of aspects pertaining to firms, including entry mode decisions (Brouthers, 2002), CSR choices (Young \& Makhija, 2014), treatment of business risks (Delios \& Henisz, 2000; Stevens, Xie, \& Peng, 2015), and performance (Cuervo-Cazurra \& Dau, 2009). La Porta, Lopez-deSilanes, Shleifer and Vishny (1998) point to variations among countries in terms of laws and enforcement mechanisms that protect investors and credit rights, showing that countries whose formal institutions are based on common law tend to offer legal rights and better protection to external shareholders than those that adopt civil law. An implication is that common law legal systems tend to encourage the development of financial markets, whereas those based on civil law tend to have fewer opportunities to raise capital through equity markets. The primary response to this institutional void is higher ownership concentration, which results in higher transaction costs.

Similarly, Djankov, La Porta, Lopez-de-Silanes and Shleifer $(2002,2003)$ demonstrate variation across countries in government regulation of new firm entry, judicial procedures in courts and labor markets. In particular, Socialist and French legal origin countries are known to regulate much more 
heavily in all three areas than common law countries (La Porta, Lopez-de-Silanes, \& Shleifer, 2002). While lower regulations allow individuals to rely on commonly accepted practices or innate beliefs, more regulated societies require individuals to pay attention to external rules that may not come naturally to them. Thus in such societies, formal rules may be less easily internalized by individuals, resulting in higher transaction costs.

While the nature of institutions can be seen to influence the conduct of business in a given environment, Khanna and Palepu (1997) pointed to those specific conditions in which institutions were either not working well or were completely absent, undermining the function and workings of the market. These conditions, referred to as 'institutional voids', can characterize any type of country, but are particularly pervasive in emerging markets. An institutional voids lens has thus helped to explain key features of emerging markets and provided greater clarity in how they differed from developed markets. Institutional voids can occur in any of a number of institutional arenas, including political, legal and social systems, foreign investment and trade-related institutions, and product, labor and capital markets (Khanna \& Palepu, 2010; Chacar, Newburry, \& Vissa, 2010). When these critical institutions operate poorly, they hinder the mechanisms that allow buyers and sellers to come together, increasing the transaction costs of market activity. These costs not only affect the connections between producers and consumers, they also dampen incentives for innovation and the leveraging of unique knowledge, talent and skills. Both Peng and Heath (1996) and Makhija (2004) have considered how the nature of transaction costs that arise from such circumstances explains why firms and their resources are structured in particular ways.

Institutional voids, whether in the form of missing or malfunctioning institutions, offer competitive advantages to those local and foreign firms that have the skills and resources to address them. Since not all are endowed with such capabilities, institutional voids may help to create monopolistic advantages for some firms. However, filling voids in such environments also come at a cost. For example, in some emerging markets it is possible to find foreign firms absorbing costs of absent institutions, by substituting for the state in building infrastructure or providing education (Banerjee, Oetzel, \& Ranganathan, 2006; Khanna \& Palepu, 2010, Rivera-Santos, Rufín, \& Kolk, 2012; Boddewyn \& Doh, 2011). Similarly, Chinese investments in Africa have included the need to develop infrastructure and programs of education for employees, the costs for which are largely absorbed by the Chinese government (Van Dijk, 2009). Even attempts to transplant formal institutions into emerging markets in which they are missing or deficient may exert profound influence on the costs of business due to their inconsistency with local modes of conduct.

Researchers have tended to stress the importance of institutional voids related to formal institutions, including those pertaining to property rights protection and capital markets (Campbell \& Lindberg, 1990; Khanna \& Palepu, 2000; Inoue, Lazzarini, \& Musacchio, 2013; Manikandan \& Ramachandran, 2015). Formal institutional voids refer to the absence or underdevelopment of regulatory institutions or the formally codified, enacted and enforced structure of laws in a community, society or nation (DiMaggio \& Powell, 1983; Scott, 1995). Only a handful of studies have considered institutional voids associated with more informal institutions or the absence or underdevelopment of normative and cognitive institutions. These include standards and commercial conventions such as those established by professional and trade associations and business groups, as well as axiomatic beliefs about expected standards of behavior that are specific to a culture and typically learned through social interactions. One noteworthy example in this regard is Boddewyn and Doh (2011), who examine the impact of inadequate local provision of social goods such as health care, infrastructure, education and the like on MNEs and the conditions under which they - either alone or in partnership with governments and NGOs provide these collective goods. Similarly, RiveraSantos et al. (2012) show that in subsistence markets where resource and institutional constraints are severe, partnerships involving multiple actors from differing sectors serve as means for alleviating institutional voids. Mair, Martí and Ventresca (2012) point out how social norms and community structure in Bangladesh can create market exclusion for impoverished women. These studies highlight how institutional voids in the social system can bring about market failure.

Firm Strategies for Addressing Institutional Voids In the face of institutional voids, the overwhelming majority of research has identified firms' strategic options as: (a) adapting their business model to local conditions by internalizing functions that 
would otherwise have been accomplished by external intermediaries, (b) shaping or altering these conditions, or (c) avoiding operating in this environment altogether. Indeed, much of the literature has focused on the first option, showing how business groups' internal markets or firm diversification help firms to adapt or adjust to institutional voids (Chang \& Hong, 2000; Elango \& Pattniak, 2007; Fisman \& Khanna, 2004; Khanna \& Palepu, 2000, 2010; Makhija, 2004). Other strategic approaches for reducing the impact of institutional voids examined include geographical clustering, in which favorable institutional conditions are created at the microcosmic level (Lundan, 2012), and alliances with foreign firms (Siegel, 2004).

Researchers have also pointed to the relevance of nonmarket responses in helping to mitigate voids (Cantwell, Dunning, \& Lundan, 2010). Potential options for nonmarket strategies include the exercise of political influence to change the form and content of regulations (Boddewyn \& Brewer, 1994; Ramamurti, 2005), coupling of interests between the state and firms (Child, Rodrigues, \& Tse, 2012; Li, Peng, \& Macaulay, 2013; Musacchio \& Lazzarini, 2014), and formation of partnerships to create and legitimize new standards in emerging markets (Teegen, Doh, \& Vachani, 2004). Narayanan and Fahey (2005) also suggest that greater reliance on interpersonal trust and networks serve as strategies to reduce risks of opportunism when formal institutions are underdeveloped.

\section{NEED FOR FURTHER RESEARCH}

As is clear from the discussion above, there has been significant progress in the literature on institutional voids. Our review suggests, however, that the literature can benefit from further study on several issues. The first relates to the nature of institutional voids. While some types of voids have been given much consideration, particularly those that are associated with formal institutions, examination of voids that are significantly different from these would help us to develop a more comprehensive understanding of this concept and its relationship to markets and firms. For example, although the absence, weakness or failure of institutions that support markets suggest an institutional vacuum, we may find that this is not always the case. Contexts characterized by underperforming formal institutions may be rich in informal institutional arrangements that serve as an alternative system of support. While current work has focused primarily on formal institutions as 'objective constraints and incentives arising from government regulation of individual and organizational actions' (Stephan, Uhlaner, \& Stride, 2015: 310), normative institutions may be equally important in this regard. While such informal institutions operate through more implicit, culturally transmitted and socially constructed processes (Scott, 1995), their enduring characteristics may explain much about how markets work. The identification and study of voids in relation to informal institutions thus deserves more attention.

It is also important to consider that institutions can fail in different aspects of their mission: regulatory, monitoring, enforcement, protection and incentivization. Such failures can affect firms' performance in contrasting ways and with varying degrees of severity. The connections between different types of failures and firm strategy are currently unclear, however. It is possible, for example, that certain types of institutional failures open up new markets for private firms to perform functions that would have otherwise been performed by the state. This may include some forms of international business. Foreign firms with a greater ability to fill institutional voids might be more likely to invest in countries that have such conditions. On the other hand, it may not be possible for firms, either local or foreign, to cover institutional functions due greater transaction costs or inability to capture value due to spillover effects. A more detailed consideration of how institutions fail and their effects on firm responses could therefore offer additional valuable insights.

In addition, while institutional voids are shown to be highly salient for market exchanges, which relate to competition for resources, revenues and profits, it would also be worthwhile to consider how firms respond to institutional voids in nonmarket exchanges. Examples of nonmarket exchanges include informal interactions among groups that shape the rules of the game (North, 1991; Puffer, McCarthy, \& Boisot, 2009). These direct the focus to norms, traditions, beliefs and also politics, both as actions and outcomes of informal institutions (Fligstein, 1996; Dhanaraj \& Khanna, 2011). Firms might use nonmarket exchanges to create or influence formal institutions where these are absent or weak. For example, foreign and local firms may informally influence the government to obtain preferential treatment and deter competition, through bribing and other forms of corruption. Corruption not only weakens institutions, but it can also jeopardize the 
functioning of markets by generating negative externalities, in which firms obtain excess rents or create monopolies (Doh, Rodriguez, Uhlenbruck, Collins, \& Eden, 2003).

Along with a more comprehensive consideration of voids, it is important to consider the possibility of a larger variety of responses by firms to institutional voids. For instance, while research has demonstrated that business groups can compensate for missing institutions by internalizing capital, labor and product markets (Fisman \& Khanna, 2004; Elango \& Pattniak, 2007; Khanna \& Palepu, 2010; Doh, Lawton, \& Rajwani, 2012), other approaches may also be useful in this regard. For example, firms can substitute for missing institutions through such means as reliance on a trusted network to mitigate risks (Landa, 2016), or develop close business-state relationships to facilitate access to otherwise scarce resources. In emerging economies with voids, the state can assist firms in ways that greatly reduce both costs and risks. In addition to fostering stronger ties to governmental entities, relationships with NGOs and other such organizations may also serve to reduce the effects of institutional voids. For example, such ties can help to overcome the absence or limited provision of social services such as health, education, transportation and utilities. Indeed, work by Dahan et al. (2010) shows how MNEs mitigate resource deficiencies in adapting their business models to institutionally challenging settings through collaboration with NGOs. The role of such collaboration for mitigating the effects of institutional voids should be examined in greater detail.

It is important to recognize that responses to voids, whether initiated by private sector actors or the state, can also potentially have negative consequences. For example, the creation of chaebols and their preferential treatment by the Korean government may have helped to foster industrial growth, but it has also impeded the development of armslength market institutions and reduced de novo entry. The Chinese government's approach of requiring well-performing state-owned firms to acquire those that are performing poorly reduces unemployment but imposes other costs on firms. Similarly, firms' choices to sidestep voids through such activities as political coalition building or provision of community services may have the unfortunate effect of maintaining institutional voids. Such activities serve the interests of powerful interest groups or political regimes, reducing their incentives to eliminate voids (Delmas \& Montes-
Sancho, 2010; Lawton, McGuire, \& Rajwani, 2012). Firms as well may prefer that some institutional voids remain in place because they deter competitive entry into their industries. Consistent with this, Wood and Frynas (2006) demonstrate that African business systems are characterized by deep and impermeable divisions between economic sectors, underpinned by elite interests in maintaining separation even at the expense of economic performance. Firm choices to address voids may also generate unexpected costs, through engagement in activities that some of their stakeholders do not associate with legitimacy (Doh et al., 2003).

Finally, voids involving different types of exchanges may require different responses from firms. The contrasting nature of these conditions may require firms to respond to institutional voids in nonmarket exchanges in very different ways than to those involving market exchanges. While performance outcomes may play a bigger role for market exchanges, greater emphasis on processes for nonmarket exchanges may render such aspects as ethical behavior, legitimacy and trustworthiness of the firm more important.

\section{CONTRIBUTIONS TO THE SPECIAL ISSUE}

The articles included in this special issue demonstrate a number of new insights relating to international business responses to institutional voids, but we will highlight two particularly important ones here. The first is that there appears to be a wider variety of strategies used by firms to deal with different types of institutional voids than previously identified. These include those relating to capital market functioning, government transparency, contract law enforcement, and rule of law. As originally highlighted by Khanna and Palepu (1997, 2000), internalization of activities remains a key approach for dealing with institutional voids. However, the studies in this volume show how multinational firms facing conditions of underdeveloped institutions in host environments can also adopt other effective strategies for mitigating their effects, including substituting institutional information with their own unique knowledge, borrowing better developed institutions from other countries, and signaling through nonmarket activities.

Second, while prior literature has focused on firms' responses to institutional voids that exist in their domestic operating environments, it is interesting to note that such voids may actually "follow" these firms to new environments through their 
foreign direct investments, as a form of liability of origin. That is, a firm from a home country characterized by significant institutional voids may be perceived in other countries as having lower investment capabilities. Multinational firms from such contexts can adopt strategies that mitigate the negative effects of these home-based voids in their host environments. Indeed, while there is evidence that firms invest abroad to escape voids in their home country (Cuervo-Cazurra, Inkpen, Musacchio, \& Ramaswamy, 2014), they also face liability of origin that reduces challenges as to their legitimacy (Pant \& Ramachandran, 2012).

Table 1 summarizes the types of institutional voids and firm responses examined in each article included in this special issue. Below, we examine these articles' contributions to the institutional voids literature.

Kim and Song's (2016) study focuses on institutional voids related to capital market development and the efficient allocation of financial resources for investment and economic growth. While wellfunctioning stock markets produce and disseminate high-quality information that improves investment decisions and the completion of transactions, less developed stock markets increase information asymmetry between buyers and sellers, and in turn, the transactions costs associated with such decisions. To shed light on this relationship, Kim and Song examine how stock market development influences abandonment of merger and acquisition deals after their public announcement. This study demonstrates that underdevelopment of capital markets increases the likelihood of costly M\&A deal abandonments for domestic firms - a form of exit strategy - whereas more developed capital markets reduce the incidence of abandoned deals due to the availability of better upfront information that can improve the quality of such deals.

Interestingly, this relationship is confirmed only for acquiring firms without affiliations with business groups. Business groups control key information and resources related to such decisions through superior internal markets that can "mimic" developed external institutions (Khanna \& Palepu, 2000). Acquiring firms affiliated with such groups are in a position to take advantage of these internal markets (Kim, Kim, \& Hoskisson, 2010; Manikandan \& Ramachandran, 2015; Chang \& Hong, 2000; Elango \& Pattniak, 2007; Fisman \& Khanna, 2004; Makhija, 2004). Thus such firms are unaffected by less developed external capital markets. Furthermore, the benefits that business group-affiliated firms derive from internal capital markets do not disappear as external capital market institutions become better developed. It appears that internal and external markets are, to some extent, interchangeable in reducing transaction costs. The focus on M\&A deal completion of this study allows us to more closely assess the effects of institutional voids on transaction costs experienced by firms, as well as better appreciate the value of an internalization strategy in reducing these transaction costs.

The article by Kingsley and Graham (2017) stresses a different type of institutional void relating to public dissemination of information that helps to inform investment decisions. They draw on Makhija and Stewart (2002), who suggest that the specific institutions employed in a given environment influence the nature of information generated in that environment. For example, well-developed stock markets such as those in the United States

Table 1 Framework for organizing the special issue articles

\begin{tabular}{|c|c|c|c|}
\hline Authors & Type of Institutions & $\begin{array}{l}\text { Nature of Institutional } \\
\text { Void }\end{array}$ & Responses to institutional Void \\
\hline $\begin{array}{l}\text { Pinkham \& } \\
\text { Peng }\end{array}$ & $\begin{array}{l}\text { Regulatory institutions related } \\
\text { to nonmarket exchange }\end{array}$ & $\begin{array}{l}\text { Weak contract } \\
\text { enforcement }\end{array}$ & $\begin{array}{l}\text { Institutional borrowing Building contract safeguards by } \\
\text { using another country's institutions }\end{array}$ \\
\hline $\begin{array}{l}\text { Graham, } \\
\text { Johnston \& } \\
\text { Kingsley }\end{array}$ & $\begin{array}{l}\text { Less formal institution that } \\
\text { supports market exchange }\end{array}$ & $\begin{array}{l}\text { Unavailability of } \\
\text { investment-related } \\
\text { information }\end{array}$ & $\begin{array}{l}\text { Substitution Using firm's private information to bridge } \\
\text { the information void for better investment decisions }\end{array}$ \\
\hline Kim \& Song & $\begin{array}{l}\text { Regulatory institutions } \\
\text { governing market exchange }\end{array}$ & $\begin{array}{l}\text { Poorly functioning capital } \\
\text { markets }\end{array}$ & $\begin{array}{l}\text { Internalization Internalizing activities to reduce } \\
\text { transaction costs }\end{array}$ \\
\hline $\begin{array}{l}\text { El-Ghoul, } \\
\text { Guedhami \& } \\
\text { Kim }\end{array}$ & $\begin{array}{l}\text { Formal \& informal institutions } \\
\text { governing market exchange }\end{array}$ & $\begin{array}{l}\text { Bureaucratic and } \\
\text { inefficient capital markets }\end{array}$ & $\begin{array}{l}\text { Signaling Using CSR to convey credibility and reduce } \\
\text { transaction costs }\end{array}$ \\
\hline $\begin{array}{l}\text { Marono, } \\
\text { Tashman \& } \\
\text { Kostova }\end{array}$ & $\begin{array}{l}\text { Informal institutions affecting } \\
\text { social exchange }\end{array}$ & $\begin{array}{l}\text { Negative attribution from } \\
\text { weak governance systems }\end{array}$ & Signaling Using CSR to enhance legitimacy \\
\hline
\end{tabular}


create demand for highly accurate and timely information on firms and the myriad of factors that have a bearing on their performance. Government dissemination of accurate information about the functioning of the economy is a valuable component of this information. The nature of such information is such that, for the most part, only governmental agencies will be in a position to ensure its availability. Thus Kingsley and Graham note that the lack of such information creates "information voids". When faced with information voids, these authors suggest that foreign investors' own private information can serve as a substitute source of information. However, variations in the private information of different types of investors - ranging from foreign direct investors, foreign portfolio investors to banks - influence its value as a substitute for this purpose. For this reason, foreign investors are not equal in their ability to manage information voids. Indeed, while bank-related investment flows are least affected by severe information voids due to their superior private information, portfolio investment flows are most negatively affected due to lack of deep knowledge of local operating conditions, and direct investment flows are moderately affected in this regard.

The study by Kingsley and Graham, which highlights the use or leveraging of the firm's own private information to stand in for missing public information, points to the conditions under which a substitution strategy is valuable for managing institutional voids. A substitution strategy is distinct from the internalization of markets approach commonly discussed in the institutional voids literature, which stresses the development of specific capabilities within the firm that will allow it to accomplish key value-creating activities on its own. The need to develop such capabilities internally stems from the inability to rely on other firms that could reliably perform the same function. Examples include the manufacturing of components inhouse when external suppliers are scarce or when inadequate contract laws lead to higher transaction costs due to opportunistic behavior of other firms, the creation of ongoing firm-specific training programs when external educational institutions are inadequate, and the development of internal sources of capital when external funding sources are limited. In contrast to such as an approach in which the firm internalizes new capabilities, functions and activities, a substitution strategy involves the reliance on a firm's already existing knowledge when information typically provided by the government is unavailable or limited, resulting in an information void. The firm will not attempt to search out or recreate the missing public information, since this requires the incurring of significant costs, and instead draw upon its private accumulated experience to proxy for it. Not all firms have private knowledge that can serve this purpose, however. The greater the information void, the more difficulty such firms will have in making good investment decisions. In this case, a substitution strategy suggests that the only option for the firm is to exit this environment.

An alternative strategy for foreign firms to respond to institutional weaknesses in the functioning of the court system and contract enforcement in one country is by explicitly drawing upon the superior court-based institutions of another country. This approach, discussed by Pinkham and Peng (2016), is called "institutional borrowing", and refers to the use of institutions from outside the domestic institutional environment. This concept has been also explored by Siegel (2005) and others as it relates to foreign firms from institutionally fragile markets "borrowing" institutions through the listing of their securities in developed country markets. In so doing, they are able to reap the legitimacy associated with the governance and oversight qualities of those markets. Building from this literature, Pinkham and Peng (2016) highlight the case of international joint ventures (IJV), for which contracts play a fundamental role in establishing the rules governing the relationship between the partners, including such features as arbitration and exit conditions (note that arbitration clauses are also common in developed country markets). It is through the contract that foreign MNEs and local firms establish the governance of the venture and adapt enforcement mechanisms to their needs. In light of this, when contractrelated institutions in the host market are weak and unreliable, transaction costs associated with the IJV's governance will increase. To mitigate the costs of enforcement, search and negotiation in such contexts, Pinkham and Peng suggest that institutional borrowing will be more likely to occur. Reliance on better functioning institutions of another country will reduce these transaction costs, and create a more efficient governance approach than relying on the host country's weaker institutions.

Even though Pinkham and Peng's article focuses on the value of institutional borrowing for a foreign firm that enters into an IJV contract in a country with poorly functioning court systems and 
inadequate contract enforcement, institutional borrowing is likely to be an effective strategy for almost any type of contractual relationship in environments with this type of institutional void. While the value of institutional borrowing is clear when foreign firms enter into contractual relationships in countries with underdeveloped contract enforcement mechanisms, such a strategy may also work for other types of cross-border business activities. For example, Li and Vashchilko (2010) suggest that cross-national security agreements serve as a form of institutional borrowing that reduces transaction costs for MNEs through lower political risks, resulting in higher bilateral investment flows between high- and low-income countries.

The next two articles of the special issue examine nonmarket strategic approaches to managing institutional voids. The study by El-Ghoul, Guedhami and Kim (2016) suggests that corporate social responsibility activities (CSR) help firms to overcome transaction costs created by a variety of institutional voids. By enhancing the firm's social capital with external stakeholders, these authors argue that CSR helps the firm reduce its risk, increase trust and improve exchange agreements. Indeed, they show that firms engaging in CSR in countries characterized by weaker capital markets, more limited business freedom, and weaker legal institutions have better business outcomes than those undertaking CSR in countries with stronger institutions. These interesting findings suggest that the value of CSR lies in the creation of strong relationships between the firm and other economic actors that translate into better access to resources. The evidence that the relationship between CSR and firm value is stronger in countries characterized by greater institutional voids support the notion that CSR is an important strategic tool in such contexts, through its ability to signal the firm's positive attributes and generate goodwill.

Drawing on a similar rationale but in a differing context, Marano, Tashman and Kostova (2016) examine the role of CSR in generating greater legitimacy for multinational firms whose home countries have significant institutional voids. The poor institutional conditions of such firms' home countries, which can include political instability, low regulatory quality and corruption, give rise to their negative stereotyping in host countries. Through reporting of CSR practices, these MNEs reduce the negative perceptions in host countries about their ability to conduct business in a legitimate manner. The authors suggest that CSR may therefore be a strategy to overcome the negative imagery associated with home country institutional voids that influence their legitimacy in their host country. Through their overall CSR activities, they are able to convey their commitment to product quality and safety, environmental and social stewardship and anti-corruption behaviors. This argument is in line with Montiel, Husted and Christmann (2012), who show that in environments characterized by governmental corruption, local firms use CSR as a means to show foreign stakeholders that they are legitimate and trustworthy partners, even in the absence of governmental authority.

Firms that operate in an environment characterized by greater institutional voids are likely to face higher costs due to reduced information flows, underdeveloped factor markets, and limited market intermediaries. In such a context, they search for ways to improve their access to vital resources and increase efficiencies. Their ability to convey to stakeholders that they are superior to other firms as members of society enhances both their reputation and visibility, and helps to form relationships in the community that can enhance preferential access to otherwise scarce resources. In this way, CSR serves as an important signaling strategy in an institutionally underdeveloped environment. As both the ElGhoul, Guedhami and Kim, and Marano, Tashman and Kostova studies suggest, CSR plays a role in distinguishing the firm from others in its home environment, enhancing its image, and improving resources. In both cases, the value of CSR to the firm increased as home institutional voids increased. It is a particularly interesting insight that home institutional voids continue to plague a firm even when it is operating away from its home country, and requires a strategic response.

The five articles included in this special issue considered a variety of different types of institutional voids, including those relating to capital market development, legal systems and contract enforcement, business restrictions, rule of law and corruption, and the production and dissemination of public information. It is clear from these studies that both domestic and foreign firms face repercussions from institutional voids, and therefore, both must develop strategic responses to them. Taken as a whole, the studies uncover four different types of strategies that can be used to address such voids. Kim and Song demonstrated the value of an internalization strategy in this regard, showing how business groups' well-developed internal markets reduce M\&A deal abandonment irrespective of the 
extent of institutional voids in capital markets. Kingsley and Graham showed the value of a substitution strategy in the face of information voids, in which foreign investors draw on their local private information to make up for the lack of local public information. Pinkham and Peng attest to the value of an institutional borrowing strategy when encountering institutional voids in contract enforcement, by which firms incorporate the superior-functioning institutions of another country in lieu of local ones into the contract. Finally, ElGhoul and co-authors point to the strategic value of a signaling strategy through CSR for enhanced access to capital and other resources in the face of different types of institutional voids. Marano and co-authors direct our attention to the effects of home country institutional voids on MNEs' perceived liability of origin in host countries, and to the benefits of signaling legitimacy through CSR to reduce these negative perceptions.

We capture the types of institutional voids investigated in the articles in this special issue by mapping them onto a $2 \times 2$ framework, with those relating to formal and informal institutions on one axis and market and nonmarket exchanges on the other. Our framework is consistent with Funk and Hirschman's (2017) argument that firms' strategies address both formal and informal institutions by market and nonmarket exchanges.

\section{SUGGESTIONS FOR FUTURE RESEARCH}

Our review of scholarship on institutional voids and the articles in the special issue demonstrate the growing contributions to this emergent literature and the progress that has been made thus far in refining theoretical conceptualizations of institutional voids and firm responses to them. Nonetheless, both IB scholarship and the articles in this special issue have their limitations, providing opportunities for additional scholarship to further extend this research domain.

It is interesting to note that virtually all research on this topic conceptualizes institutional voids as constraints. This message is also evident in the studies published in this volume: In countries with institutional voids, firms need to figure out how to respond. Whether through internal markets within business groups (Kim \& Song, 2016), using their own private knowledge (Kingsley \& Graham, 2017), engaging in corporate social responsibility (ElGhoul, Guedhami, \& Kim, 2016; Marano, Tashman, \& Kostova, 2016), borrowing institutions from elsewhere (Pinkham \& Peng, 2016), or exiting (Kim \& Song, 2016; Kingsley \& Graham, 2017), simply reacting may be a more passive approach. It may be that a more proactive approach, in which firms attempt to change their institutional environment, yields greater benefits. For instance, work in institutional theory views institutional voids as prevalent at the interface between absent/weak formal institutions and multiple informal institutions. It is argued that such institutional pluralism provides room for discretionary action (Kraatz \& Block, 2008). In other words, institutional voids are understood as 'opportunity spaces' for agency (Mair \& Martí, 2009; Saka-Helmhout \& Geppert, 2011; McKague, Zietsma, \& Oliver, 2015; Venkataraman et al., 2016). Given that organization-specific advantages evolve through actively innovating around institutions (Cantwell et al., 2010), rather than through passive countering measures, there is a significant opportunity for IB scholarship to investigate ways in which institutional voids enable market and nonmarket actors to shape and transpose institutions in the pursuit of competitive advantage.

Much of the current literature assumes that actors' incentives and expectations are shaped primarily by formal rules. However, as some of the studies in this special issue have suggested, we risk losing much of what drives responses to institutional voids by adopting such a narrow focus. We therefore suggest that future research gives more rigorous attention to voids related to both formal and information institutions, including comparison of their relative effects on firm strategies.

While limitations in formal institutions are more easily observed, informal institutions are also likely to play a more significant role in affecting voids than currently conceptualized. The weak or fluid nature of institutions in emerging markets suggests that activities of firms revolve more around social networks and on family or other social connections (e.g., Dieleman \& Boddewyn, 2012). For example, even though societal beliefs about women had not been previously related to institutional voids, Mair et al. (2012) shed important light on the systematic influence of this cultural norm on access to entrepreneurial opportunities. It is likely that other informal institutions also have an influence on the functioning of markets and creation of voids. Thus a broader consideration of both formal and informal institutions will provide us with a more indepth understanding of both the causes and consequences of institutional voids. 
Future research can also reflect more on how formal and informal institutions interact with each other. The nature of this interaction may be reinforcing, accommodating, substituting, or competing (Helmke \& Levitsky, 2004). Depending on whether informal institutions reinforce/substitute for or compete with formal institutions, firms can be exposed to different strengths of institutional voids. For example, when informal institutions fill gaps by addressing contingencies that are not completely addressed by formal rules, they may enhance efficiency. In this way, existence of complementary institutions may reduce the extent of institutional voids. Similarly, substitutive informal institutions may take the place of formal institutions that are either missing or ineffective. On the other hand, certain informal institutions may actually compete with formal institutions, resulting in voids. An illustration of this would be an institutional environment in which a legal system with reasonably strong contract law coexists with informal institutions that stress relationship-based transactions. Such conflicting institutions may influence how contracts are enforced, possibly resulting in incomplete contracts and/or creating greater uncertainties in their enforcement.

Although the issue of informal institutions substituting for formal ones has figured in the IB literature as an important dynamic on how firms interact with home and host country institutional voids, we still know little about how firms and governments as interdependent actors (Campbell \& Lindberg, 1990) are informally influenced by institutions and also shape them. In addition, international business research has not yet given sufficient attention to market failures, how they result in corruption, rent seeking and market power. Doh et al. (2003) documented the recursive relationship between social and economic underdevelopment and corruption, illustrating that institutional fragility begets economic and social indigence which, in turn, further erodes institutions. Under these conditions, MNEs are deterred from investing or they greatly reduce their exposure, especially when corruption is arbitrary and unpredictable. We would encourage further exploration of the conditions when institutional voids are too severe to mitigate, such as those occurring in so-called fragile or failing states.

Research on institutional change is still at a nascent stage in international business research (Carney et al., 2016). We know little about the risks created by systemic institutional failures and their effects on international business, despite some scholarly effort to understand them (Oh \& Oetzel, 2011). When ongoing failure of formal institutions results in their continual change, the uncertainty that emanates from this change may itself create all sorts of market distortions (e.g., low trust, abuse by more powerful economic actors such as banks or large firms, endemic corruption among politicians, and so on), and result in higher transaction costs for both local and foreign firms. In such situations, causes and consequences are difficult to disentangle making it difficult for firms to diagnose the nature of the voids they are facing. It may be useful

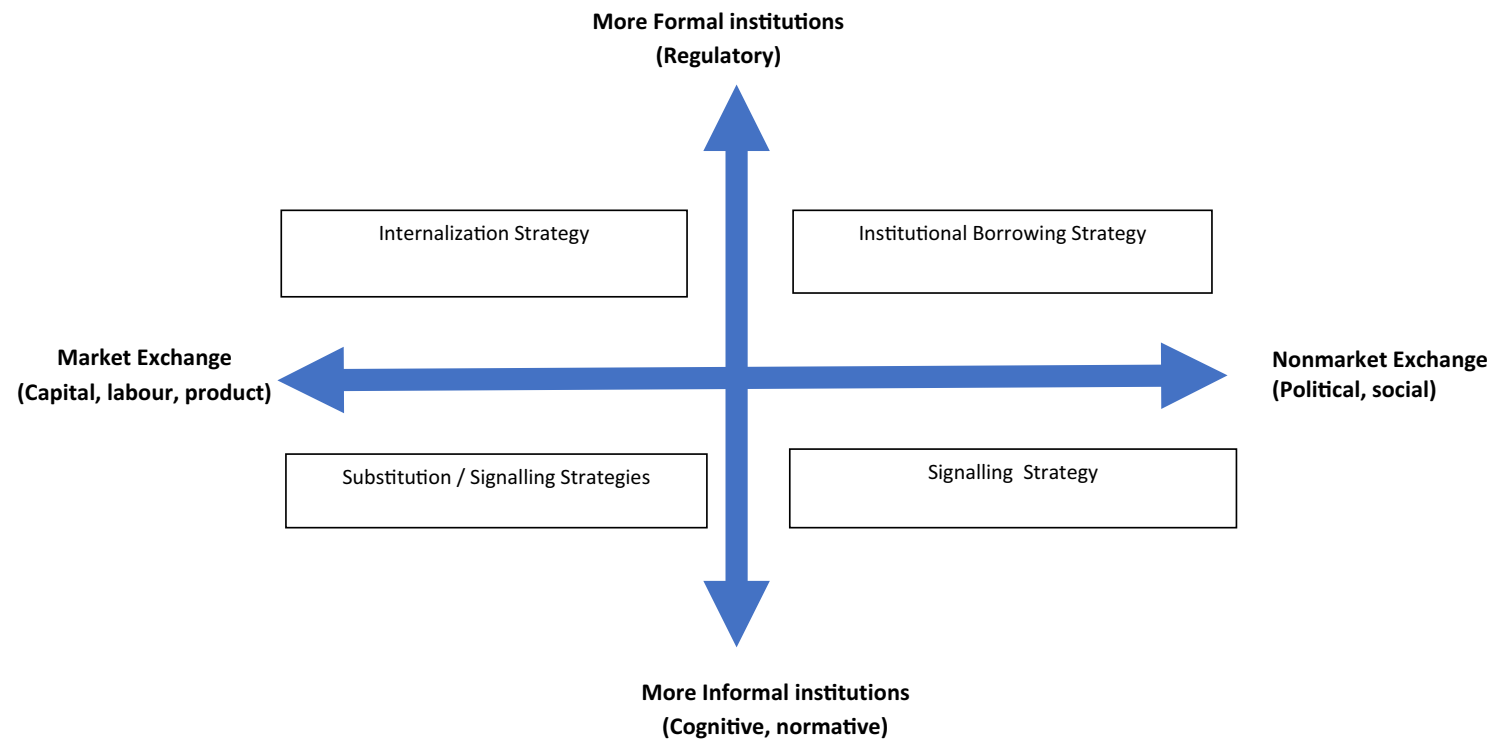

Figure 1 Responses to institutional voids. 
for IB scholars to consider in greater depth how such organizational decisions are made, drawing upon and extending prior work that has examined how foreign firms respond to complex environmental challenges (Child \& Rodrigues, 2011; Rivera-Santos et al., 2012).

The studies included in this special issue have shed some light on how firms respond to different types of institutional voids. We offered a preliminary framework, presented in Figure 1, showing the varying types of responses firms might adopt in relation to voids stemming from different institutional conditions. We believe that further testing and refinement of this framework will enhance our understanding of firms' responses to voids. While we suggest that voids vary in terms of the nature of institutions and type of exchange undertaken, in turn influencing the nature of responses that best address them, we may not have captured the range of possible responses that might suitably address voids. Research comparing different approaches adopted by firms for addressing similar types of voids would be very helpful in providing insights on which strategies are most appropriate for reducing specific transaction costs. Future research might also consider possible spillover or contagion effects of responses to institutional voids. As firms adopt similar approaches to institutional voids, they may

\section{REFERENCES}

Banerjee, S. G., Oetzel, J. M., \& Ranganathan, R. 2006. Private provision of infrastructure in emerging markets: Do institutions matter? Development Policy Review, 24(2): 175-202.

Biggart, N. W., \& Delbridge, R. 2004. Systems of exchange. Academy of Management Review, 29(1): 28-49.

Boddewyn, J., \& Doh, J. 2011. Global strategy and the collaboration of MNEs, NGOs, and governments for the provisioning of collective goods in emerging markets. Global Strategy lournal, 1: 345-361.

Boddewyn, J. J., \& Brewer, T. L. 1994. International-business political behavior: New theoretical directions. Academy of Management Review, 19: 119-143.

Boddewyn, J., \& Doh, J. P. 2011. Global strategy and the collaboration of MNEs, governments and NGOs for the provisioning of collective goods in emerging markets. Global Strategy Journal, 1: 345-361.

Brouthers, K. D. 2002. Institutional, cultural and transaction cost influences on entry mode choice and performance. Journal of International Business Studies, 33(2): 203-221.

Campbell, J. L., \& Lindberg, L. N. 1990. Property rights and the organization of economic activity by the state. American Sociological Review, 634-647.

Cantwell, J., Dunning, J. H., \& Lundan, S. M. 2010. An evolutionary approach to understanding international business activity: The co-evolution of MNEs and the institutional environment. Journal of International Business Studies, 41: 567-586. also develop parallel competencies. Furthermore, it is possible that firms' responses to voids result in valuable competencies that more effectively reduce transaction costs than relying on external institutions. Approaches such as these are likely to provide important new insights into how institutional voids impact firms.

\section{ACKNOWLEDGMENTS}

We thank former Editor-in-Chief John Cantwell, Tarun Khanna, and three anonymous reviewers for helpful feedback on this article.

\section{NOTE}

${ }^{1}$ Signaling explains behavior under information asymmetry, and is used by one party to indicate its level of credibility to another (Spence, 1973, 2002; Sliwka, 2007). While this notion has broad application to the functioning of markets, the four strategies discussed here differ in the emphasis placed on signaling. The primary objective of a signaling strategy is to convey information to others, whereas the role of signaling is less central to the other three.

Carney, M., Dieleman, M., \& Taussig, M. 2016. How are institutional capabilities transferred across borders? Journal of World Business, 51(6): 882-894.

Chacar, A. S., Newburry, W., \& Vissa, B. 2010. Bringing institutions into performance persistence research: Exploring the impact of product, financial, and labor market institutions. Journal of International Business Studies, 41: 1119-1140.

Chang, S. J., \& Hong, J. 2000. Economic performance of groupaffiliated companies in Korea: Intragroup resource sharing and internal business transactions. Academy of Management Journal, 43: 429-448.

Child, J., Lu, Y., \& Tsai, T. 2007. Institutional entrepreneurship in building an environmental protection system for the People's Republic of China. Organization Studies, 28: 1013-1034.

Child, J., \& Rodrigues, S. B. 2011. How organizations engage with external complexity: A political action perspective. Organization Studies, 32(6): 803-824.

Child, J., Rodrigues, S. B., \& Tse, K. K.-T. 2012. The dynamics of influence in corporate co-evolution. Journal of Management Studies, 49: 1246-1273.

Child, J., \& Tse, D. K. 2001. China's transition and its implications for international business. Journal of International Business Studies, 32: 5-21.

Cuervo-Cazurra, A., \& Dau, L. A. 2009. Promarket reforms and firm profitability in developing countries. Academy of Management Journal, 52: 1348-1368.

Cuervo-Cazurra, A., \& Genc, M. 2008. Transforming disadvantages to advantages: Developing-country MNEs in the least 
developed countries. Journal of International Business Studies, 39: 957-979.

Cuervo-Cazurra, A., Inkpen, A., Musacchio, A., \& Ramaswamy, K. 2014. Governments as owners: State-owned multinational companies. Journal of International Business Studies, 45(8): 919-942.

Dahan, N., Doh, J. P., Oetzel, J., \& Yaziji, M. 2010. CorporateNGO collaboration: Creating new business models for developing markets. Long Range Planning, 43: 326-342.

Deeg, R. 2005. Change from within: German and Italian finance in the 1990s. In W. Streeck \& K. Thelen (Eds.), Beyond Continuity: Institutional Change in Advanced Political Economies: 169-202. Oxford: Oxford University Press.

Delios, A., \& Henisz, W. I. 2000. Japanese firms' investment strategies in emerging economies. Academy of Management Journal, 43(3): 305-323.

Delmas, M. A., \& Montes-Sancho, M. J. 2010. Voluntary agreements to improve environmental quality: Symbolic and substantive cooperation. Strategic Management Journal, 31: 575-601.

Dhanaraj, C., \& Khanna, T. 2011. Transforming mental models on emerging markets. Academy of Management Learning \& Education, 10(4): 684-701.

Dieleman, M., \& Boddewyn, J. 2012. Using organization structure to buffer political ties in emerging markets: A case study. Organization Studies, 33: 71-95.

DiMaggio, P. I., \& Powell, W. W. 1983. The iron cage revisited: Institutional isomorphism and collective rationality in organizational fields. American Sociological Review, 48: 147-160.

Djankov, S., La Porta, R., Lopez-de-Silanes, F., \& Shleifer, A. 2002. The regulation of entry. Quarterly Journal of Economics, 117: $1-37$

Djankov, S., La Porta, R., Lopez-de-Silanes, F., \& Shleifer, A. 2003. Courts. Quarterly Journal of Economics, 118: 453-517.

Doh, J. P., Lawton, T. C., \& Rajwani, T. 2012. Advancing nonmarket strategy research: Institutional perspectives in a changing world. Academy of Management Perspectives, 26: 22-39.

Doh, J. P., Rodriguez, P., Uhlenbruck, K., Collins, J., \& Eden, L. 2003. Coping with corruption in foreign markets. The Academy of Management Executive, 17(3): 114-127.

El-Ghoul, S., Guedhami, O., \& Kim, Y. 2016. Country-level institutions, firm value, and the role of corporate social responsibility initiatives. Journal of International Business Studies. doi:10.1057/jibs.2016.4.

Elango, B., \& Pattniak, C. 2007. Building capabilities for international operations through networks: A study of Indian firms. Journal of International Business Studies, 38: 541-555.

Fisman, R., \& Khanna, T. 2004. Facilitating development: The role of business groups. World Development, 32: 609-628.

Fligstein, N. 1996. Markets as politics: A political-cultural approach to market institutions. American Sociological Review, 656-673.

Funk, R. J., \& Hirschman, D. 2017. Beyond nonmarket strategy: Market actions as corporate political activity. Academy of Management Review, 42(1): 32-52.

Granovetter, M. 1985. Economic action and social structure: The problem of embeddedness. American Journal of Sociology, 91(3): 481-510.

Helmke, G., \& Levitsky, S. 2004. Informal institutions and comparative politics: A research agenda. Perspectives on Politics, 2(04): 725-740.

Hoskisson, R. E., Eden, L., Lau, C. M., \& Wright, M. 2000. Strategy in emerging economies. Academy of Management Journal, 43: 249-267.

Inoue, F., Lazzarini, S., \& Musacchio, A. 2013. Leviathan as a minority shareholder: Firm-level implications of equity purchases by the state. Academy of Management Journal, 56(6): 1775-1801.

Keefer, P., \& Knack, S. 1997. Why don't poor countries catch up? A cross-national test of an institutional explanation. Economic Inquiry, 35(3): 590-602.
Khanna, T., \& Palepu, K. G. 1997. Why focused strategies may be wrong for emerging markets. Harvard Business Review, 75: $41-51$

Khanna, T., \& Palepu, K. G. 2000. The future of business groups in emerging markets: Long-run evidence from Chile. Academy of Management Journal, 43: 268-285.

Khanna, T., \& Palepu, K. G. 2010. (with Richard Bullock).Winning in emerging markets: A road map for strategy and execution. Boston: Harvard Business Press.

Khanna, T., \& Yafeh, Y. 2007. Business groups in emerging markets: Paragons or parasites? Journal of Economic Literature, 45(2): 331-372. (Reprinted and adapted in The Oxford Handbook of Business Groups, edited by A. M. Colpan, T. Hikino, and J. R. Lincoln, Oxford handbooks in business and management series. Oxford University Press, July 2010).

Kim, H., Kim, H., \& Hoskisson, R. E. 2010. Does market-oriented institutional change in an emerging economy make businessgroup-affiliated multinationals perform better? An institutionbased view. Journal of International Business Studies, 41: 1141-1160.

Kim, H., \& Song, J. 2016. Filling institutional voids in emerging economies: The impact of capital market development and business groups on M\&A deal abandonment. Journal of International Business Studies. doi:10.1057/s41267-016-0025-0.

Kingsley, A. F., \& Graham, B. A. T. 2017. The effects of information voids on capital flows in emerging markets. Journal of International Business Studies. doi:10.1057/s41267016-0056-6.

Kostova, T., \& Hult, G. T. M. 2016. Meyer and Peng's 2005 article as a foundation for an expanded and refined international business research agenda: Context, organizations, and theories. Journal of International Business Studies, 47(1): 23-32.

Kraatz, M. S., \& Block, E. S. 2008. Organizational implications of institutional pluralism. In R. Greenwood, C. Oliver, K. Sahlin, \& R. Suddaby (Eds.), Handbook of Organizational Institutionalism: 243-275. London: Sage.

La Porta, R., Lopez-de-Silanes, F., \& Shleifer, A. 2002. Government ownership of banks, 57: 265-301.

La Porta, R., Lopez-de-Silanes, F., Shleifer, A., \& Vishny, R. W. 1998. Law and finance. Journal of Political Economy, 106: 1113-1155.

Landa, J. T. 2016. Cognitive and classificatory foundations of trust and informal institutions: A new and expanded theory of ethnic trading networks. In Economic Success of Chinese Merchants in Southeast Asia: 173-189. Springer Berlin Heidelberg.

Lawton, T., McGuire, S., \& Rajwani, T. 2012. Corporate political activity: A literature review and research agenda. International Journal of Management Reviews, 15: 86-105.

Li, J., Newenham-Kahindi, A., Shapiro, D. M., \& Chen, V. Z. 2013. The two-tier bargaining model revisited: Theory and evidence from China's natural resource investments in Africa. Global Strategy Journal, 3(4): 300-321.

Li, Y., Peng, M. W., \& Macaulay, C. D. 2013. Market-political ambidexterity during institutional transitions. Strategic Organization, 11: 205-213.

Li, Q., \& Vashchilko, T. 2010. Dyadic military conflict, security alliances, and bilateral FDI flows. Journal of International Business Studies, 41(5): 765-782.

Lundan, S. M. 2012. The new eclectic paradigm and international business strategy. In A. Verbeke \& H. Merchant (Eds.), Handbook of Research on International Strategic Management: 64-76. Cheltenham: Edward Elgar.

Mair, J., \& Martí, I. 2009. Entrepreneurship in and around institutional voids: A case study from Bangladesh. Journal of Business Venturing, 24: 419-435.

Mair, J., Martí, I., \& Ventresca, M. 2012. Building inclusive markets in rural Bangladesh: How intermediaries work institutional voids. Academy of Management Journal, 55: 819-850.

Makhija, M. 2004. The value of restructuring in emerging economies: The case of the Czech Republic. Strategic Management Journal, 25(3): 243-265. 
Makhija, M., \& Stewart, A. 2002. The effect of the institutional environment on perceptions of risk: A comparison of planned versus free-market managers. Journal of International Business Studies, 33(4): 737-757.

Manikandan, K. S., \& Ramachandran, J. 2015. Beyond institutional voids: Business groups, incomplete markets, and organizational form. Strategic Management Journal, 36(4): 598-617.

Marano, V., Tashman, P., \& Kostova, T. 2016. Escaping the iron cage: Liabilities of origin and CSR reporting of emerging market multinational enterprises. Journal of International Business Studies. doi:10.1057/jibs.2016.17.

McKague, K., Zietsma, C., \& Oliver, C. 2015. Building the social structure of a market. Organization Studies, 36(8): 1063-1093.

Meyer, K. E., Estrin, S., Bhaumik, S. K., \& Peng, M. W. 2009. Institutions, resources, and entry strategies in emerging economies. Strategic Management Journal, 30(1): 61-80.

Meyer, K. E., \& Peng, M. W. 2016. Theoretical foundations of emerging economy business research. Journal of International Business Studies, 47(1): 3-22.

Meyer, J. W., \& Rowan, B. 1977. Institutionalized organizations: Formal structures as myth and ceremony. American Journal of Sociology, 83: 340-363.

Miller, D., Lee, J., Chang, S., \& Breton-Miller, I. L. 2009. Filling the institutional void: the social behavior and performance of family vs. non-family technology firms in emerging markets. Journal of International Business Studies, 40: 802-817.

Montiel, I., Husted, B. W., \& Christmann, P. 2012. Using private management standard certification to reduce information asymmetries in corrupt environments. Strategic Management Journal, 33(9): 1103-1113.

Musacchio, A., \& Lazzarini, S. G. 2014. Reinventing State Capitalism: Leviathan in Business, Brazil and Beyond. Boston: Harvard University Press.

Narayanan, V. K., \& Fahey, L. 2005. The relevance of the institutional underpinnings of Porter's five forces framework to emerging economies: an epistemological analysis. Journal of Management Studies, 42: 207-223.

North, D. C. 1990. Institutions, institutional change and economic performance. Cambridge: Cambridge University Press.

North, D. C. 1991. Institutions STÖR. The Journal of Economic Perspectives, 5(1): 97-112.

Oh, C. H., \& Oetzel, J. 2011. Multinationals' response to major disasters: How does subsidiary investment vary in response to the type of disaster and the quality of country governance? Strategic Management Journal, 32(6): 658-681.

Pant, A., \& Ramachandran, J. 2012. Legitimacy beyond borders: Indian software services firms in the United States, 1984 to 2004. Global Strategy Journal, 2(3): 224-243.

Peng, M. W., \& Heath, P. S. 1996. The growth of the firm in planned economies in transition: Institutions, organizations, and strategic choice. Academy of Management Review, 21(2): 492-528.

Peng, M. W., Sun, S. L., Pinkham, B., \& Chen, H. 2009. The institution-based view as a third leg for a strategy tripod. Academy of Management Perspectives, 23: 63-81.

Peng, M. W., Wang, D. Y. L., \& liang, Y. 2008. An institutionbased view of international business strategy: A focus on emerging economies. Journal of International Business Studies, 39: 920-936.

Pinkham, B. C., \& Peng, M. W. 2016. Overcoming institutional voids via arbitration. Journal of International Business Studies. doi:10.1057/s41267-016-0026-z.

Pinkse, J., \& Kolk, A. 2012. Multinational enterprises and climate change: Exploring institutional failures and embeddedness. Journal of International Business Studies, 43(3): 332-341.

Puffer, S. M., McCarthy, D. I., \& Boisot, M. 2009. Entrepreneurship in Russia and China: The impact of formal institutional voids. Entrepreneurship Theory and Practice, 34: 441-467.
Ramamurti, R. 2005. Global regulatory convergence: The case of intellectual property rights. In R. Grosse (Ed.), International Business and Government Relations in the 21st Century: 341-360. Cambridge: Cambridge University Press.

Regnér, P. \& Edman, J. 2014. MNE institutional advantage: How subunits shape, transpose and evade host country institutions. Journal of International Business Studies, 45: 275-301.

Ricart, J.-E., Enright, M. J., Ghemawat, P., Hart, S. L., \& Khanna, T. 2004. New frontiers in international strategy. Journal of International Business Studies, 35: 519-534.

Rivera-Santos, M., Rufín, C., \& Kolk, A. 2012. Bridging the institutional divide: Partnerships in subsistence markets. Journal of Business Research, 65(12): 1721-1727.

Robinson, J. A., Torvik, R., \& Verdier, T. 2006. Political foundations of the resource curse. Journal of Development Economics, 79: 447-468.

Saka-Helmhout, A., \& Geppert, M. 2011. Different forms of agency and institutional influences within multinational enterprises. Management International Review, 51: 567-592.

Santangelo, G., \& Meyer, K. 2011. Extending the internationalization process model: Increases and decreases of MNE commitment in emerging markets. Journal of International Business Studies, 42: 894-909.

Scott, W. R. 1995. Institutions and Organizations. Thousand Oaks, CA: Sage.

Siegel, I. 2004. Do foreign firms choose not to cross-list because they have secured better alternatives? Commitment mechanism than cross-listings for emerging economy firms? Evidence from Mexico. Journal of International Business Studies, 40: 1171-1191.

Siegel, J. 2005. "Can foreign firms bond themselves effectively by renting US securities laws?". Journal of Financial Economics, 75: 319-359.

Sliwka, D. 2007. Trust as a signal of a social norm and the hidden costs of incentive schemes. American Economic Review, 97: 999-1012.

Spence, M. 1973. Job market signaling. Quarterly Journal of Economics, 87: 355-374.

Spence, M. 2002. Signaling in retrospect and the informational structure of markets. American Economic Review, 92: 434-459.

Stephan, U., Uhlaner, L., \& Stride, C. 2015. Institutions and social entrepreneurship: the role of institutional voids, institutional support, and institutional configurations. Journal of International Business Studies, 46(3): 308-331.

Stevens, C. E., Xie, E., \& Peng, M. W. 2015. Toward a legitimacy-based view of political risk: the case of Google and Yahoo in China. Strategic Management Journal, 37(5): 945-963.

Teegen, H., Doh, J. P., \& Vachani, S. 2004. The importance of nongovernmental organizations (NGOs) in global governance and value creation: an international business research agenda. Journal of International Business Studies, 35: 463-483.

Tracey, P., \& Phillips, N. 2011. Entrepreneurship in emerging markets: strategies for new venture creation in uncertain institutional contexts. Management International Review, 51: 23-39.

van Dijk, M. P. 2009. The new presence of China in Africa. Amsterdam: Amsterdam University Press.

Venkataraman, H., Vermeulen, P., Raaijmakers, A., \& Mair, J. 2016. Market meets community: institutional logics as strategic resources for development work. Organization Studies, 37(5): 709-733.

Wood, G., \& Frynas, J. G. 2006. The institutional basis of economic failure: anatomy of the segmented business system. Socio-Economic Review, 4: 239-277.

Wright, M., Filatotchev, I., Hoskisson, R. E., \& Peng, M. W. 2005. Guest Editors' introduction: Strategy research in emerging economies: challenging the conventional wisdom. Journal of Management Studies, 42: 1-33. 
Young, S. L., \& Makhija, M. V. 2014. Firms' corporate social responsibility behavior: An integration of institutional and profit maximization approaches. Journal of International Business Studies, 45(6): 670-698.

\section{ABOUT THE AUTHORS}

Jonathan Doh is Rammrath Chair in International Business, Faculty Director, Center for Global Leadership, and Professor of Management at the Villanova School of Business. Previously he was on the faculty of American and Georgetown, a trade official with the U.S. government, and a consultant to Deloitte. His research on international business and corporate responsibility has been published in 75 journal articles, ten books and more than 35 chapters. He is Editor- in-Chief of Journal of World Business and an elected Fellow of the Academy of International Business. He holds a Ph.D. in strategic and international management from George Washington University.

Suzana B. Rodrigues is Professor of International Business at FUMEC University Brazil, Emeritus Professor of International Business at Erasmus University Rotterdam School of Management and is Beaufort Visiting Scholar, St. John's College, University of Cambridge. She does research on emerging markets - firms' strategic responses to differing institutional environments. Her work derives from research on multinationals in the mining and automotive industries, and on entrepreneurial firms in biotech and software industries. Her research has been published in, Journal of Management Studies, Organization Studies, Management and Organization Review, Journal of International Management, Management International Review,
Corporate Governance: An International Review, Journal of Management and Governance and Human Relations.

Ayse Saka-Helmhout is Associate Professor of International Management at Nijmegen School of Management, Radboud University. Her research focuses on how MNEs display agency despite their institutional embeddedness. Her work has highlighted responses by MNEs to multiple institutional pressures from a comparative perspective. She has published on these issues in journals such as Journal of Management Studies, Organization Studies, Journal of World Business, and Management International Review. She is currently embarked on a project funded by the Food \& Business Knowledge Platform of the Dutch Ministry of Foreign Affairs to investigate the effectiveness of networks in agribusiness that is characterized by institutional voids.

Mona Makhija is Professor of International Business at the Fisher College of Business, The Ohio State University. Her research focuses on how institutional features of national environments affect the strategies and structure of firms, nature of competition and behavior of managers. Her work also examines global strategies of multinational firms and the effects of organizational control and coordination mechanisms on the management of knowledge. Makhija has published her research in a number journals, including Academy of Management Review, Journal of International Business Studies, Strategic Management Journal, Organization Science, Global Strategy Journal, and others. Until recently, she served as Area Editor for Journal of International Business Studies. 